\title{
Recovery of exponentially growing cultures of Klebsiella pneumoniae NCIB 418 after heat shocks
}

\author{
A. Heitzer and G. Hamer \\ Eidgenössische Technische Hochschule, Institut für Biotechnologie, Überlandstrasse 133, CH-8600 Dübendorf, Switzerland
}

\begin{abstract}
Exponentially growing cultures of Klebsiella pneumoniae were subjected to heat shocks in the superoptimal and supermaximal temperature ranges for growth on glucose in a defined mineral salts medium. Transitory changes in the specific growth rate constant during recovery were evident. The response was heat shock temperature and exposure time dependent. Cell viability determinations, based on colony counts, indicated complete recovery from heat treatments at superoptimal temperatures. In contrast, at supermaximal temperatures, discrepancies in colony counts on different agars were observed. The kinetic response of the specific growth rate constant after a heat shock at supermaximal temperatures is explained by segregation within the bacterial population
\end{abstract}

Key words: Heat shock - Superoptimal/supermaximal temperature - Recovery - Specific growth rate constant Klebsiella pneumoniae - Population - Injury

The development of a better understanding of the response of bacteria to short term heat shocks at temperatures above their optimum for growth and product formation has recently gained in importance, because temperature inducible expression systems for the controlled expression of genes in recombinant bacteria are finding increasing application as alternatives to certain metabolite induced expression systems (Anderson Da Silva and Bailey 1989). One such system involves the temperature-sensitive $\lambda$ repressor cI857 with either a $\lambda \mathrm{P}_{\mathrm{L}}$ or $\mathrm{P}_{\mathrm{R}}$-promoter, where, to obtain high degrees of expression, bacteria have to be subjected to a temperature shift to and maintenance at $42^{\circ} \mathrm{C}$ (Lastick et al. 1986). Another system consists of a lac promoter carried on an attnutL-p-att-N gene block which inverts when the bacteria into which this has been introduced are subjected to $42^{\circ} \mathrm{C}$ for $10 \mathrm{~min}$, thereby causing expression of the combined gene (Podhajska et al. 1985). The latter heat shocking could be accomplished by passage of the bacteria through a heat exchanger and subsequent return to a favourable growth temperature, as opposed to prolonged retention of the bacteria at a superoptimal temperature, that, clearly, is poten-

Offprint requests to: $\mathrm{G}$. Hamer tially injurious to them. The purpose of the present work was to study the effects of short term heat shocks on the growth kinetics of a bacterial population during subsequent recovery.

\section{Methods \\ Organism and cultivation conditions}

Klebsiella pneumoniae NCIB 418 was grown in batch culture in a bioreactor (Bioengineering AG, Wald, Switzerland) with an operating volume of 1.41. The temperature and the impeller speed were controlled at $35^{\circ} \mathrm{C}$ and 800 r.p.m., respectively. The $\mathrm{pH}$ was maintained constant at 6.8 by automatic addition of either an equimolar $2 \mathrm{M} \mathrm{NaOH} / \mathrm{KOH}$ mixture or a $10 \%(\mathrm{w} / \mathrm{w})$ solution of $\mathrm{H}_{3} \mathrm{PO}_{4}$. The aeration rate was $351 \mathrm{~h}^{-1}$. The growth medium was a defined mineral salts medium (Evans et al. 1970) modified by replacing citric acid with $55 \mathrm{mg}^{-1} \mathrm{Na}_{2}$ EDTA, whilst $2.5 \mathrm{~g} \mathrm{l}^{-1}$ glucose served as the sole carbon energy source. The medium used for the heat treatment and recovery experiments contained $1 \mathrm{~g}^{-1}$ glucose and was buffered with a $\mathrm{Na}_{2} \mathrm{HPO}_{4} / \mathrm{KH}_{2} \mathrm{PO}_{4}$ mixture $\left(0.1 \mathrm{M}\right.$ for $\left.\mathrm{PO}_{4}^{3-}\right)$ at $\mathrm{pH} 6.8$.

Heat treatment: Cells were removed from the bioreactor at a predetermined optical density of 1.8 , measured at $546 \mathrm{~nm}$, i.e., during the mid-exponential growth phase. Aliquots of $2 \mathrm{ml}$ were immediately transferred into preheated stirred flasks of $100 \mathrm{ml}$ total volume containing $20 \mathrm{ml}$ of culture medium in which the glucose concentration was identical with that in the bioreactor at the time of inoculum removal. The temperatures used for heat shocking were $42^{\circ} \mathrm{C}, 45^{\circ} \mathrm{C}, 46.5^{\circ} \mathrm{C}, 48^{\circ} \mathrm{C}$ and $51^{\circ} \mathrm{C}$. Exposure times were 1, 3 or 5 min. For each series of experiments a control was processed at $35^{\circ} \mathrm{C}$. For recovery, the whole content of each flask was transferred into a second stirred $500 \mathrm{ml}$ flask containing $180 \mathrm{ml}$ of the same medium maintained at $35^{\circ} \mathrm{C}$.

Growth measurement: Samples were removed at either 6 or 12 min intervals and growth was measured as the increase in the absorbance at $546 \mathrm{~nm}$ (OD) using an Uvikon 860 spectrophotometer (Kontron AG, Zürich, Switzerland). The apparent specific growth rate constant $(\mu)$ at $\mathbf{t}_{\mathbf{n}}=0.5$ $\left(t_{2}+t_{1}\right)$ was calculated according to the equation:

$$
\mu\left(t_{n}\right)=\left[O D\left(t_{2}\right)-O D\left(t_{1}\right)\right] /\left[0.5\left(O D\left(t_{1}\right)+O D\left(t_{2}\right)\right)\left(t_{2}-t_{1}\right)\right]
$$




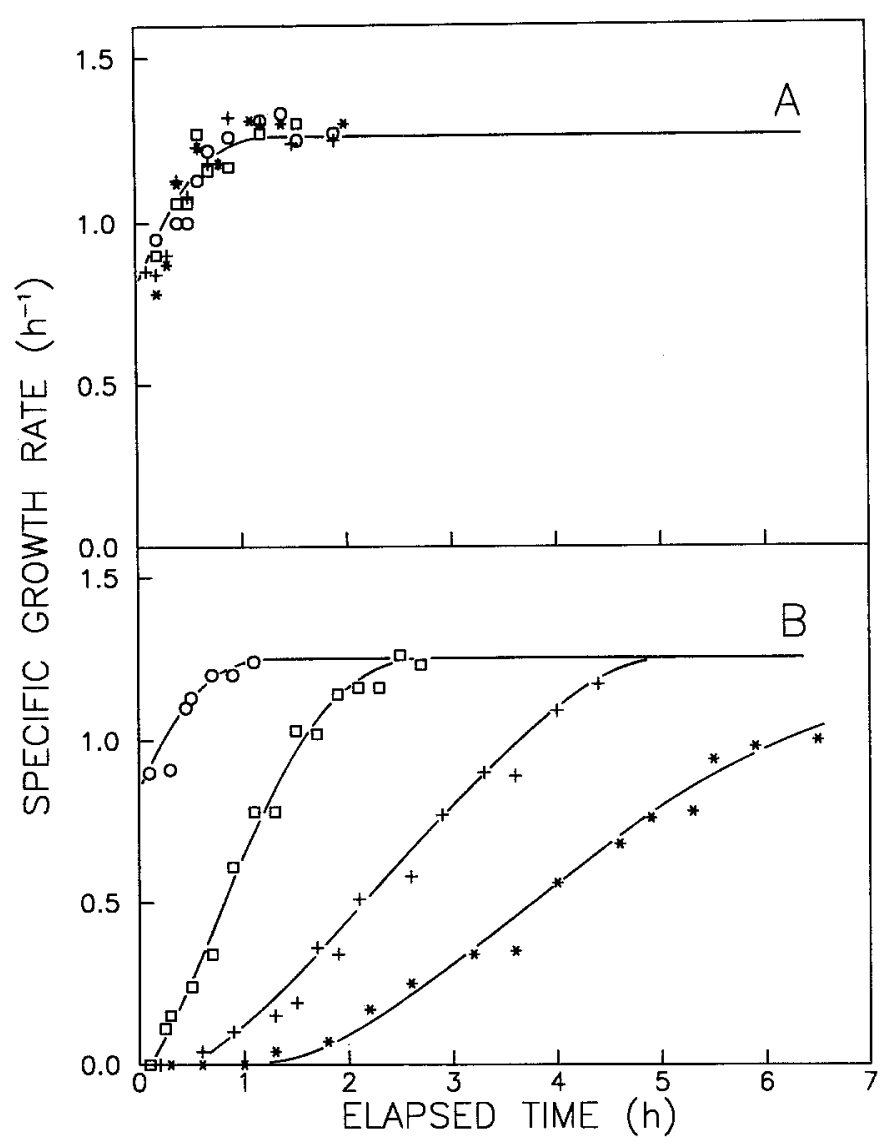

Fig. 1A, B. Time course of the specific growth rate during recovery of $K$. pneumoniae cultures after heat shocks at $42^{\circ} \mathrm{C}(\mathrm{A})$ and $48^{\circ} \mathrm{C}$ (B). Exposure times were $0(\bigcirc), 1(\square) 3(+)$ and $5(*)$ min. The initial specific growth rate constants of the cultures before the heat treaments were $1.23 \mathrm{~h}^{-1}(\mathbf{A})$ and $1.20 \mathrm{~h}^{-1}(\mathbf{B})$

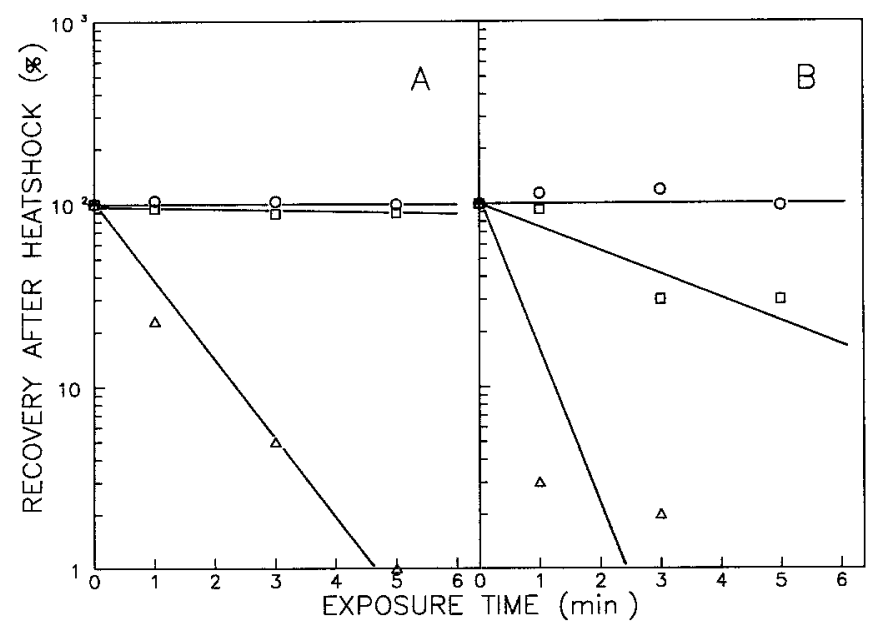

Fig. 2 A, B. Survival of $K$. pneumoniae after heat shocks at $45^{\circ} \mathrm{C}$ (O), $48^{\circ} \mathrm{C}(\square)$, and $51^{\circ} \mathrm{C}(\triangle)$ on two different agars: (A) plate count agar, (B) glucose agar

where $t$ is the time of sample removal in hours and the subscripts 1 and 2 represent initial and final conditions.

All the experiments were carried out either in duplicate or in triplicate and data points represent mean values.

Plate counts: PCA plates are prepared with $2.35 \mathrm{~g} \mathrm{l}^{-1}$ plate count agar (Difco, Detroit, USA) and $13.5 \mathrm{gl}^{-1}$ Bacto
Table 1. Recovery times for $K$. pneumoniae cultures subjected to several heat shocks for different exposure times; for definition of recovery time see text

\begin{tabular}{llrr}
\hline $\begin{array}{l}\text { Heat shock } \\
\text { temperature } \\
\left({ }^{\circ} \mathrm{C}\right)\end{array}$ & \multicolumn{2}{l}{ Recovery time $(\mathrm{h})$} \\
\cline { 2 - 3 } & \multicolumn{2}{l}{ Exposure time (min) } \\
\cline { 2 - 3 } & 1 & 2 & 5 \\
\hline 42 & $<0.2$ & $<0.2$ & $<0.2$ \\
45 & 0.2 & 0.4 & 0.5 \\
46.5 & 0.4 & 0.8 & 1.3 \\
48 & 1.3 & 3.3 & 5.8 \\
51 & 5.5 & 18.3 & $>18.3$ \\
\hline
\end{tabular}

agar (Difco, Detroit, USA) supplemented with $1 \mathrm{~g}^{-1}$ glucose and buffered at $\mathrm{pH} 6.8$ with $\mathrm{Na}_{2} \mathrm{HPO}_{4} / \mathrm{KH}_{2} \mathrm{PO}_{4}$ $\left(0.05 \mathrm{M}^{2} \mathrm{PO}_{4}^{3-}\right)$. BG plates were prepared by addition of $15 \mathrm{~g} \mathrm{l}^{-1}$ Bacto Agar to the mineral medium used for growth experiments, supplemented with $2 \mathrm{~g} \mathrm{l}^{-1}$ glucose and buffered at $\mathrm{pH}$ 6.8. After sample dilution and plating, colonies were counted after incubation at $35^{\circ} \mathrm{C}$ for $48 \mathrm{~h}$. The counts were carried out in quintuplicate. The results presented are mean values.

\section{Results}

Exponentially growing cultures of $K$. pneumoniae were subjected to heat shocks at either superoptimal $\left(42^{\circ} \mathrm{C}, 45^{\circ} \mathrm{C}\right)$ or supermaximal $\left(46.5^{\circ} \mathrm{C}, 48^{\circ} \mathrm{C}, 51^{\circ} \mathrm{C}\right)$ temperatures, for the growth of the bacterium on glucose as its sole carbon energy substrate. Response patterns were temperature and exposure time dependent as shown in the results for $42^{\circ} \mathrm{C}$ and $48^{\circ} \mathrm{C}$ in Fig. 1. Superoptimal heat shocks were either insignificant $\left(42^{\circ} \mathrm{C}\right)$ or resulted in transitory, slightly exposure time dependent, decrease of the specific growth rate constant $\left(45^{\circ} \mathrm{C}\right)$. In Fig. 1B the response of $K$. pneumoniae to a heat shock which is clearly in the supermaximal region $\left(48^{\circ} \mathrm{C}\right)$ is shown. An initial lag phase where no growth occurred, was followed by an acceleration phase with respect to the growth rate constant. The recovery times exhibited by $K$. pneumoniae to attain the initial specific growth rate constant of a control, after the several heat treatments, are given in Table 1. Recovery time was defined as the time required for a heat shocked culture to attain the initial growth rate constant of the control.

In Fig. 2 the survival patterns of $K$. pneumoniae plated both on plate count agar and on a minimal glucose agar after different heat shocks are shown. Heat treatments at $45^{\circ} \mathrm{C}$ for all exposure times investigated allowed complete recovery on both agars. In contrast, discrepancies in colony counts occurred at $48^{\circ} \mathrm{C}$. Whilst heat treatment for $5 \mathrm{~min}$ allowed essentially complete recovery on plate count agar, an exposure time dependent reduction in survival was observed on minimal glucose agar. At $51^{\circ} \mathrm{C}$ a reduction in survival on both agars was observed, but was most pronounced on the minimal glucose agar. Figure 3 shows the results of a calculation for the prediction of recovery from a 5 min heat shock at $48^{\circ} \mathrm{C}$ assuming a segregated bacterial population that initially comprizes a viable cell fraction of 0.3 and a non-viable fraction of 0.7 (for equations see Appendix). The relative ratios were estimated on the basis of colony 


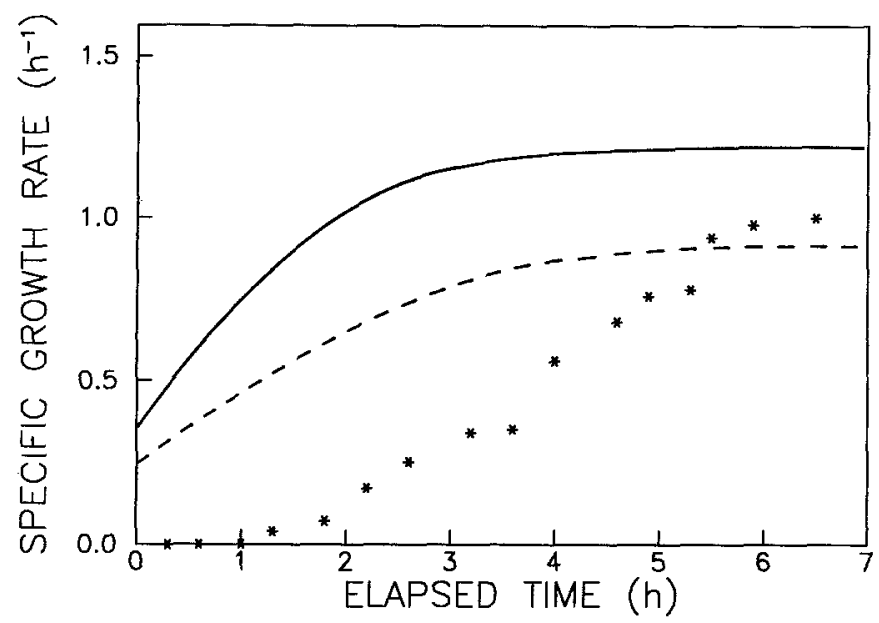

Fig. 3. Recovery of $K$. pneumoniae after $5 \mathrm{~min}$ heat shock at $48^{\circ} \mathrm{C}$. Comparison between experimental data $(*)$ and responses based on calculations assuming a segregated population consisting of an initially constant non-viable fraction of 0.7 and a viable portion of 0.3 which was able to grow at a constant rate of either $0.9 \mathrm{~h}^{-1}$ (dashed curve) or $1.22 \mathrm{~h}^{-1}$ (continuous curve)

counts observed on glucose agar. Calculations were performed for two different growth rate constants of the viable cell fraction: $1.22 \mathrm{~h}^{-1}$, the maximum value at $35^{\circ} \mathrm{C}$ and $0.9 \mathrm{~h}^{-1}$, which corresponded to the initial growth rate constant of the control. Neither of the simulations resulted in either reasonable quantitative or qualitative approximations of the experimental response.

\section{Discussion and conclusions}

The exposure of exponentially growing cultures of $K$. pneumoniae to various heat shocks results in both transitory reductions in the specific growth rate constant and significant lag phases, depending on shock intensity. Possible bases for such responses are that at superoptimal temperatures, bacterial growth is generally reduced (Esener et al. 1981) and, that step changes in growth temperature can result in pronounced time delays with respect to adjustment of the specific growth rate constant (Ryu and Mateles 1968; Ingraham 1987).

Since the maximum growth temperature for $K$. pneumoniae in minimal medium with glucose as sole carbon energy substrate is between $45^{\circ} \mathrm{C}$ and $46^{\circ} \mathrm{C}$, response patterns to the heat shocks were divided into two groups (Franks et al. 1980), i.e., those in the superoptimal temperature range where balanced growth is still possible and those in the supermaximal temperature range where the maximum growth temperature is exceeded and growth does not occur. Short term heat shocks in the superoptimal temperature range result in recovery patterns which suggest that bacterial injury was insignificant, thereby confirming earlier results for $K$. pneumoniae when cells from a chemostat were heat shocked by passage through a heat exchanger (Heitzer et al. 1989). Although short term heat shocks in the superoptimal temperature region do not seem to cause major damage such temperatures can significantly alter the levels of many enzymes (Herendeen et al. 1979). These latter changes can occur very rapidly. Yamamori and Yura (1980) reported that the induction of synthesis of heat shock proteins in $E$. coli after a step increase from $30^{\circ} \mathrm{C}$ to $42^{\circ} \mathrm{C}$ was initiated within $60 \mathrm{~s}$. Such energy consuming metabolic alterations probably take place at the expense of the maximum growth rate, an explanation consistent with the response observed here after subjecting $K$. pneumoniae to a heat shock at $45^{\circ} \mathrm{C}$.

Heat shocks at supermaximal temperatures resulted in much more pronounced effects that were strongly temperature stress and exposure time dependent. Colony counts on minimal glucose agar for heat shocks at $48^{\circ} \mathrm{C}$ showed significant reduction in survival, suggesting that a part of the culture lost its capacity to recover, leading to the conclusion that recovery patterns must be interpreted by segregation of the bacterial population into a viable fraction and a non viable fraction (Hamer and Heitzer 1990). Calculations conducted for a $5 \mathrm{~min}$ heat shock at $48^{\circ} \mathrm{C}$ on this basis resulted in the prediction of much faster recovery than was, in fact, observed (Fig. 3), suggesting that the viable cell fraction must also have temporally lost its capacity to grow at its maximum rate, probably due to reversible damage. Earlier, Takano and Tsuchido (1982) concluded that growth delays in exponentially growing cultures of $E$. coli, after heat stress at supermaximal temperatures, were partially due to an increase in reversible injury to the viable fraction. For recovery after a supermaximal temperature shock, Daniels et al. (1984) reported that it took $>2 \mathrm{~h}$ for complete restoration of normal protein synthesis in Halobacterium volcanii. In the present experiments, the apparently non-viable fraction of the bacterial population present after heat shocks at $48^{\circ} \mathrm{C}$ should not be considered as a dead fraction, since recovery was found to be complete on protein rich plate count agar, on which the maximum growth temperature for $K$. pneumoniae is between $47^{\circ} \mathrm{C}$ and $48^{\circ} \mathrm{C}$. In contrast, heat shocks at $51^{\circ} \mathrm{C}$ resulted in reduced viable counts on both agar media, indicating that this heat treatment was lethal to a fraction of the population. The previous history of bacteria before subjecting them to a heat shock can significantly affect recovery. Jenkins et al. (1988) cited prior starvation as enhancing thermal resistance relative to exponentially growing bacteria, whilst prior treatment at a superoptimal temperature when subjecting bacteria to supermaximal heat shocks enhances survival (Van Bogelen et al. 1989; Ramsey 1988). Another important question advanced by van Uden and Madeira-Lopes (1976), concerns the contribution of a non-viable fraction in a microbial population to substrate consumption. From the present study it is clear that the choice of an appropriate host organism, when a recombinant strain with a temperature regulated expression system is constructed, depends on both its optimum and its maximum temperature for growth, particularly when growth after heat shocking is required.

\section{Appendix}

The change in total biomass, $x_{t}$, during recovery after a heat shock for a segregated bacterial population comprizing a viable fraction $x_{v}$ and a non-viable fraction $x_{n}$ at time $t$ is given by

$\mathrm{x}_{\mathrm{t}}(\mathrm{t})=\mathrm{x}_{\mathrm{n}}+\mathrm{x}_{\mathrm{v}}(\mathrm{t})$.

The viable cells contribution to growth a time $t$ is given by

$\mathrm{x}_{\mathrm{v}}(\mathrm{t})=\mathrm{x}_{\mathrm{v}}(\mathrm{t}=0) \mathrm{e}^{\mu \mathrm{t}}$

where $\mu$ is the specific growth rate constant of the viable fraction. Combination of equation (A2) and (A1) results in: 
$\mathrm{x}_{\mathrm{i}}(\mathrm{t})=\mathrm{x}_{\mathrm{n}}+\mathrm{x}_{\mathrm{y}}(\mathrm{t}=0) \mathrm{e}^{\mu \mathrm{t}}$.

For a small time interval $\left(t_{n+1}+t_{n}\right)$, where $t_{n}$ and $t_{n+1}$ are initial and final times respectively, the apparent growth rate $\mu_{\mathrm{a}}$ at time $\mathrm{t}_{\mathrm{a}}=0.5\left(\mathrm{t}_{\mathrm{n}+1}+\mathrm{t}_{\mathrm{n}}\right)$, is given by:

$\mu_{a}\left(t_{a}\right)=\left[x_{i}\left(t_{n+1}\right)-x_{t}\left(t_{n}\right)\right] /\left[0.5\left(x_{t}\left(t_{n+1}\right)+x_{t}\left(t_{n}\right)\right)\left(t_{n+1}-t_{n}\right)\right]$

Application of equation (A4) for different times allows predictions of the type shown in Fig. 3 to be made.

\section{References}

Anderson Da Silva N, Bailey JE (1989) Construction and characterization of a temperature-sensitive expression system in recombinant yeast. Biotechn Prog 5:18-26

Daniels CJ, McKee AHZ, Doolittle WF (1984) Archaebacterial heat-shock proteins. EMBO J 3:745 - 749

Esener AA, Roels JA, Kossen NWF (1981) The influence of temperature on the maximum specific growth rate of Klebsiella pneumoniae. Biotechn Bioeng 23:1401-1405

Evans CGT, Herbert D, Tempest DW (1970) The continuous cultivation of microorganisms. In: Norris JR, Ribbons DW (eds) Methods in microbiology, vol 2. Academic Press, London, pp $277-327$

Franks PA, Hall RJ, Linklater PM (1980) Mechanistic model of the growth of Streptococcus cremoris HP at superoptimal temperatures. Biotechn Bioeng 22:1465-1487

Hamer G, Heitzer A (1990) Fluctuating environmental conditions in scaled-up bioreactors - heating and cooling effects. Ann N Y Acad Sci in press

Heitzer A, Al-Awadhi N, Hamer G (1989) Some effects of heat shocks on bacterial growth. Appl Microbiol Biotechn 30:408414

Herendeen SL, Van Bogelen RA, Neidhardt FC (1979) Levels of major proteins of Escherichia coli during growth at different temperatures. J Bacteriol 139:185-194
Ingraham J (1987) Effect of temperature, $\mathrm{pH}$, water activity, and pressure on growth. In: Neidhardt FC (ed) Escherichia coli and Salmonella typhimurium: cellular and molecular biology, vol 2. American Society for Microbiology, Washington D.C., pp $1543-1554$

Jenkins DE, Schultz JE, Matin A (1988) Starvation-induced cross protection against heat or $\mathrm{H}_{2} \mathrm{O}_{2}$ challenge in Escherichia coli. J Bacteriol 170:3910 - 3914

Lastick SM, Tucker MY, Mackedonsky V, Grohmann K (1986) Overproduction of $E$. coli xylose isomerase. Biotechnol Lett $8: 1-6$

Podhajska AJ, Hasan N, Szybalski W (1985) Control of cloned gene expression by promoter inversion in vivo: construction of the heat-pulse-activated att-nutL-p-att- $N$ module. Gene 40:163168

Ramsay N (1988) A mutant in a major heat shock protein of Escherichia coli continues to show inducible thermotolerance. Mol Gen Genet 211:332-334

Ryu DY, Mateles RI (1968) Transient response of continuous cultures to changes in temperature. Biotechn Bioeng 10:385-397

Takano M, Tsuchido T (1982) Availability of growth delay analysis for the evaluation of total injury of stressed bacterial populations. J Ferment Techn 60:189-198

Van Bogelen RA, Acton MA, Neidhardt FC (1987) Induction of the heat shock regulon does not produce thermotolerance in Escherichia coli. Genes \& Development 1:525-531

Uden N van, Madeira-Lopes A (1976) Yield maintenance relations of yeast growth in the chemostat at superoptimal temperatures. Biotechn Bioeng 18:791-804

Yamamori T, Yura T (1980) Temperature-induced synthesis of specific proteins in Escherichia coli: Evidence for transcriptional control. J Bacteriol 142:843-851

Received July 6, 1989/Accepted October 2, 1989 